\title{
VELOCITY FLUCTUATIONS OF THE BERSÆKERBRÆ, EAST GREENLAND
}

\author{
By T. W. Friese-Greene and G. J. Pert \\ (Imperial College Exploration Board, London, England)
}

\begin{abstract}
The results of measurements of surface flow and ablation on the glacier Bersækerbræ, in the Staunings Alper, East Greenland, are presented. A correlation is shown between the rate of flow and rate of ablation, as suggested by current theory.

RÉsumé. Fluctuations de la vitesse du glacier de Bersakerbra (est du Groenland). Les résultats des mesures d'écoulement en surface et d'ablation du glacier du Bersækerbræ (Staunings Alper, Est du Groenland) sont présentés. Une corrélation a été établie entre la vitesse d'écoulement et la vitesse d'ablation, comme le suggérait une théorie actuelle.

Zusammenfassung. Geschwindigkeitsschwankungen am Bersakerbra, Ost-Grönland. Die Ergebnisse von Messungen der Geschwindigkeit und der Ablation auf der Oberfläche des Bersækerbræ, Staunings Alper, OstGrönland, werden mitgeteilt. Zwischen den Änderungen der Geschwindigkeit und der Ablation zeigen sich Abhängigkeiten, wie sie nach der derzeitigen Theorie zu erwarten sind.
\end{abstract}

\section{INTRODUGTION}

A part of the glaciological programme of the r963 Imperial College East Greenland Expedition was to measure the flow of the glacier Bersækerbræ in the Staunings Alper (lat. $72^{\circ}$ Io $^{\prime}$ N., long. $24^{\circ} 30^{\prime}$ W.). Observations were made of flow and ablation at three stake lines across the glacier during July and August 1963 .

The Bersækerbræ is a valley glacier of type II of Ahlmann's classification (Ahlmann, I 948, p. 6r ). It is about $22 \mathrm{~km}$. long flowing north-east from its own collection grounds.

When the observation ceased at the end of August the snow line was at $900 \mathrm{~m}$. On the basis of the fall-off of ablation that was then occurring and the previous rise of the snow line, it is estimated that the firn line was at about $\mathrm{I}, 000 \mathrm{~m}$. in 1963 . Observations in the higher areas indicate that the glacier is sub-polar (Ahlmann, I948, p. 66). Despite this most of the discharge is provided by two large rivers emerging from under the glacier along the bedrock floor.

There is one major tributary glacier, from the Dunottar Gletscher; observation of moraines indicate that it probably supplies about a quarter of the total ice in the glacier. The Tårnfjeld Gletscher has now retreated and no longer has any ice-contact with the main glacier. The Harlech Gletscher is now dead, contributing only a patch of almost stagnant moraine-covered ice on the west side of the glacier (Fig. I).

There is a small ice fall on the east side of the glacier between the middle and lower stake lines. This is apparently due to a protruding spur and indicates that the ice in this area must be fairly thin.

\section{Stake Lines}

Three transverse and one longitudinal stake lines were established for surface flow measurements in the lower $7 \mathrm{~km}$. of the glacier. In this region the glacier flows round a bend as the valley turns due east to join Skeldal. The map (Fig. 2) indicates the positions of the lines and the photograph (Fig. 3) shows the glacier above the ice fall, including the upper two lines.

Two types of markers were used. On bare ice, i I ft. $(3.4 \mathrm{~m}$.) pine stakes were drilled $8 \mathrm{ft}$. $(2.4 \mathrm{~m}$.) into the ice, using a hand auger. This depth proved sufficient to avoid the necessity of re-drilling, only one stake (in the lower line) becoming loose in the last period of observation. On medial moraines small stones were used as markers in the transverse lines. These were painted with a cross, put in a small hollow and covered with a large stone; measurements were made to the cross. These markers proved very satisfactory and no disturbance was observed. 
The movements of the transverse lines was measured by the offset technique. The displacements were directly measured along the direction of flow by taping from the line between a pair of cairns one on each side of the glacier. The cairns for the top and bottom lines were established on rock at the side of the glacier; but those for the middle line had to be built on dead moraine.

The stakes on the longitudinal line were surveyed from the two nearest cairns used for offsets. The distance between cairns was obtained from surveying a measured base line. Measurements of stake positions were made once during each eight-day period, providing six sets of readings.

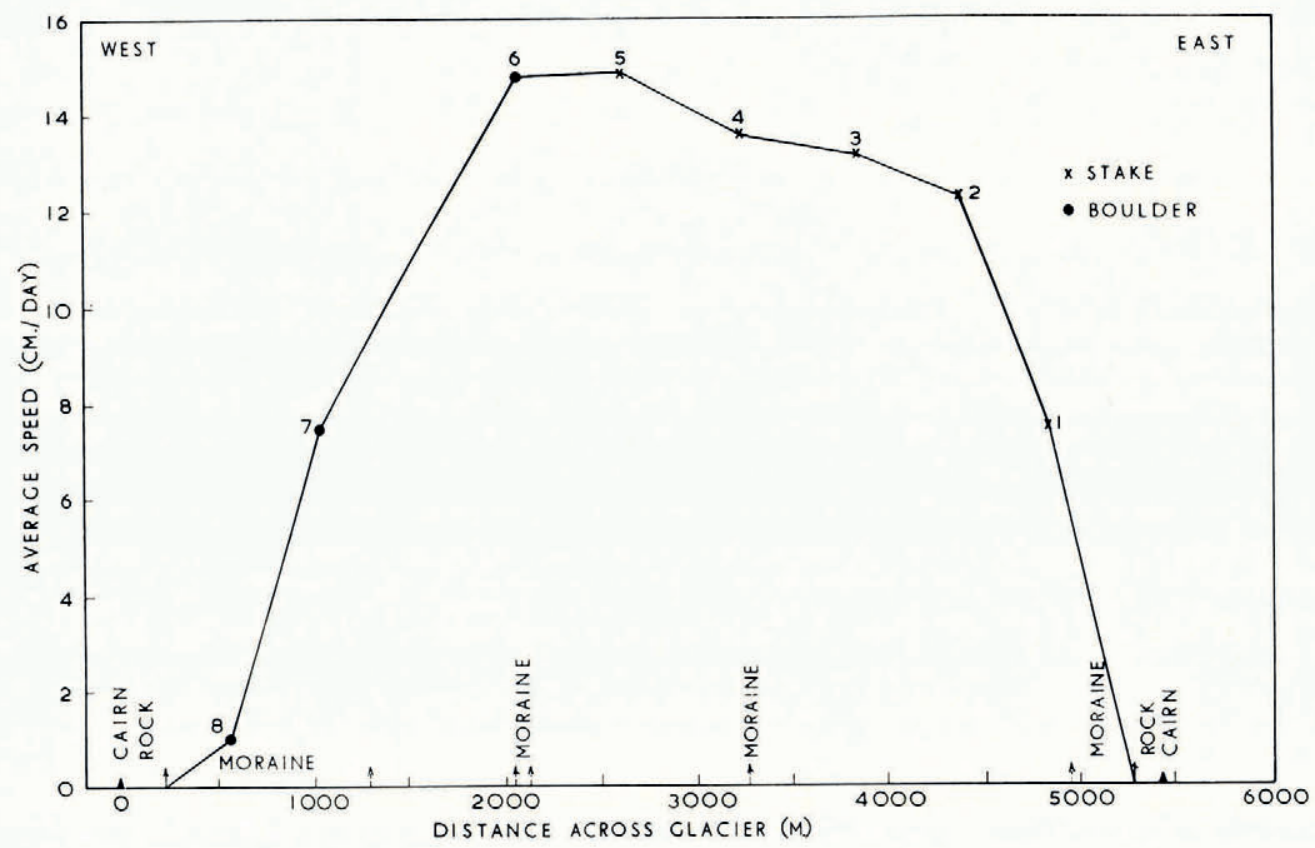

Fig. I. The velocity profile for the top stake line. The region of slowly moving ice on the west is from the Harlech Glacier

For practical reasons offsets were taken to the point where the stake entered the ice thus causing a systematic error due to ablation and non-vertical alignment of the stakes. This was eliminated in the longitudinal line by measuring to the flag on the top. The error of measurement in the transverse stake lines was found as the root-mean-square deviation of a series of readings to be about $\mathrm{I}$ in. $(2 \cdot 5 \mathrm{~cm}$.). In the subsequent analysis of the results using random fluctuation theory this became insignificant. The error in the movement of the longitudinal stakes was also estimated as $\mathrm{I}$ in. $(2 \cdot 5 \mathrm{~cm}$.).

Ablation measurements were made at each stake in the transverse lines at the same time as the displacement was observed. The density of the ice was never measured, so absolute values of the ablation are not known. However, except for the top line, the stakes were drilled into ice; the top line being covered with about $3 \mathrm{in} .(7 \cdot 5 \mathrm{~cm}$.) of coarse firn at the time of drilling. It is therefore assumed that the measured ablation (i.e. change in glacier level) was proportional to the quantity of ice melting. 


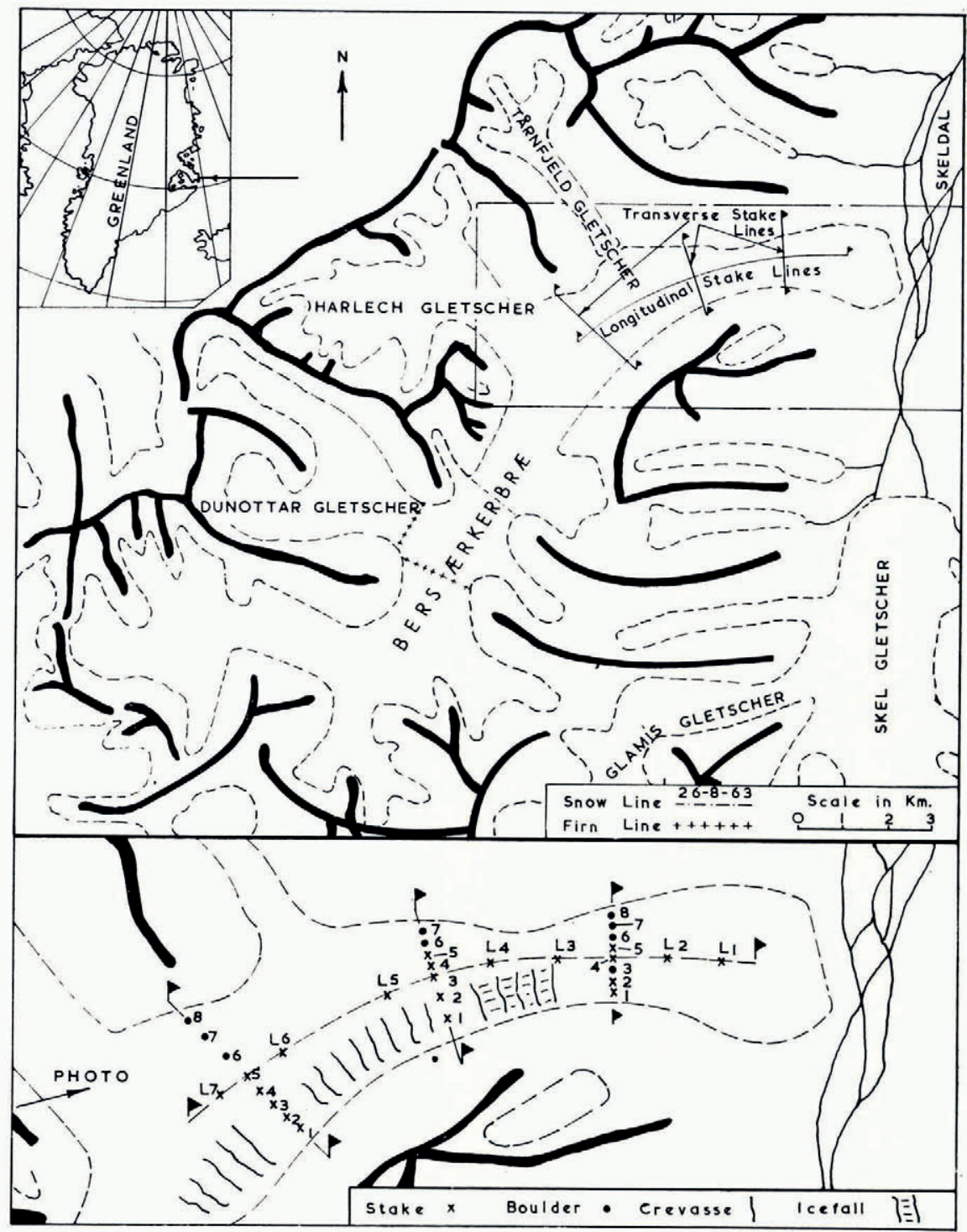

Fig. 2. Map of Bersakerbre showing the stake lines and marker positions. Also shown are the firn line and snow line at 26 August 1963

\section{Results}

The profile of surface flow across the glacier at the top stake line is shown in Figure $\mathrm{I}$. The shape of this profile is more uneven than those of the other lines and shows a reduced speed on the west side (stake 8) caused by the decaying ice from the almost stagnant Harlech Gletscher. This marker (8) moved slowly and as its error was large in comparison to movement it was neglected in the subsequent analysis.

In all the profiles the maximum flow lies slightly to the west of centre due to the increase in speed towards the outside edge associated with the glacier moving round the bend. 
In Figure 4 the displacement of the stakes in the top line is plotted against the time of observation. The slope of the lines drawn between neighbouring points gives the average speed in that period. If we compare the general form of the flow for all the stakes we see that a definite pattern is shown, which is followed by nearly all the markers. The speed was high in the first period and dropped markedly in the second. During the third period the glacier speeded up, but slowed slightly in the fourth. In the fifth there was little change.

If we compare these trends with those of the ablation shown on the same graph we see there is a distinct similarity. If the flow increased so did the ablation and vice versa. Thus we have a definite correlation between the ablation and the flow rates on this stake line.

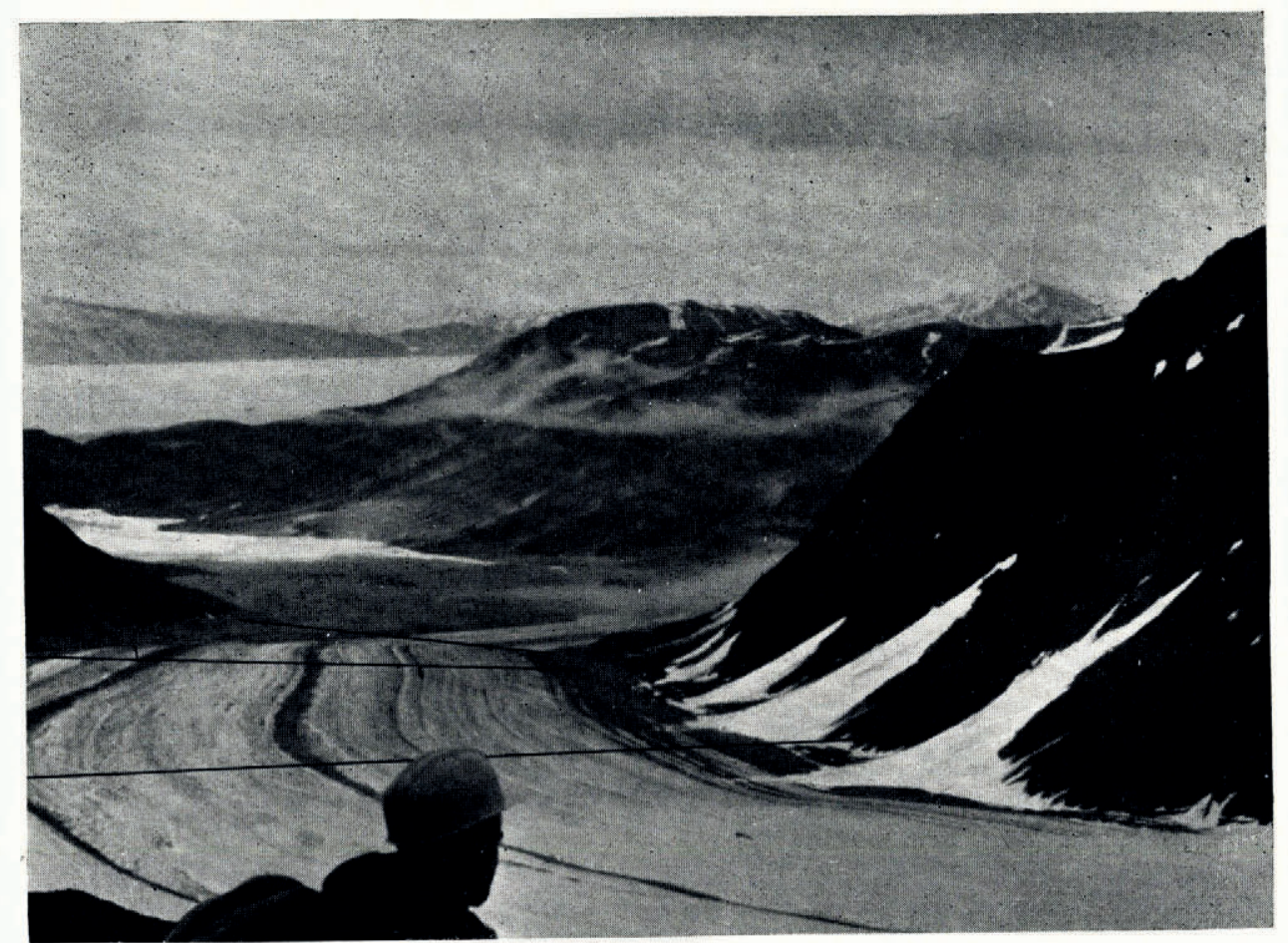

Fig. 3. Photograph of Bersakerbra showing the section in which the measurements were made on the left. The three transverse stake lines are marked with the lowest just visible below the ice fall in the centre of the photograph

Inspection of Figure 5 on which the displacement and ablation of the middle line are plotted shows the same correlation as for the top markers. The bottom line shown in Figure 6 shows no clearly defined pattern of flow which is followed by all the stakes, and thus shows little correlation with the fairly constant ablation rate. Possible reasons for this will be discussed later.

In order to check that this correlation between ablation and flow rates was a definite phenomenon and not just a coincidence, a procedure based on random fluctuation statistics was adopted. It should be noticed that most variations are outside the estimated error of measurement, and are too large to be accounted for by the systematic error due to nonvertical alignment of stakes (which in any case does not apply to marker stones). Each stake line was considered as an integral unit and variations of flow from a normalized mean value were considered random. Every measurement for each stake was converted to an average 
velocity over the period between the two readings. This velocity was then divided by the mean velocity of the marker over the whole period of observation to normalize it. A mean normalized velocity for each stake line during this period was calculated and an error estimated assuming the deviations of individual stakes from the mean over the line random. The latter procedure is questionable but a check, based on calculating the percentage of readings lying within one root-mean-square deviation indicated that it was satisfactory. The ablation results were treated in the same way.

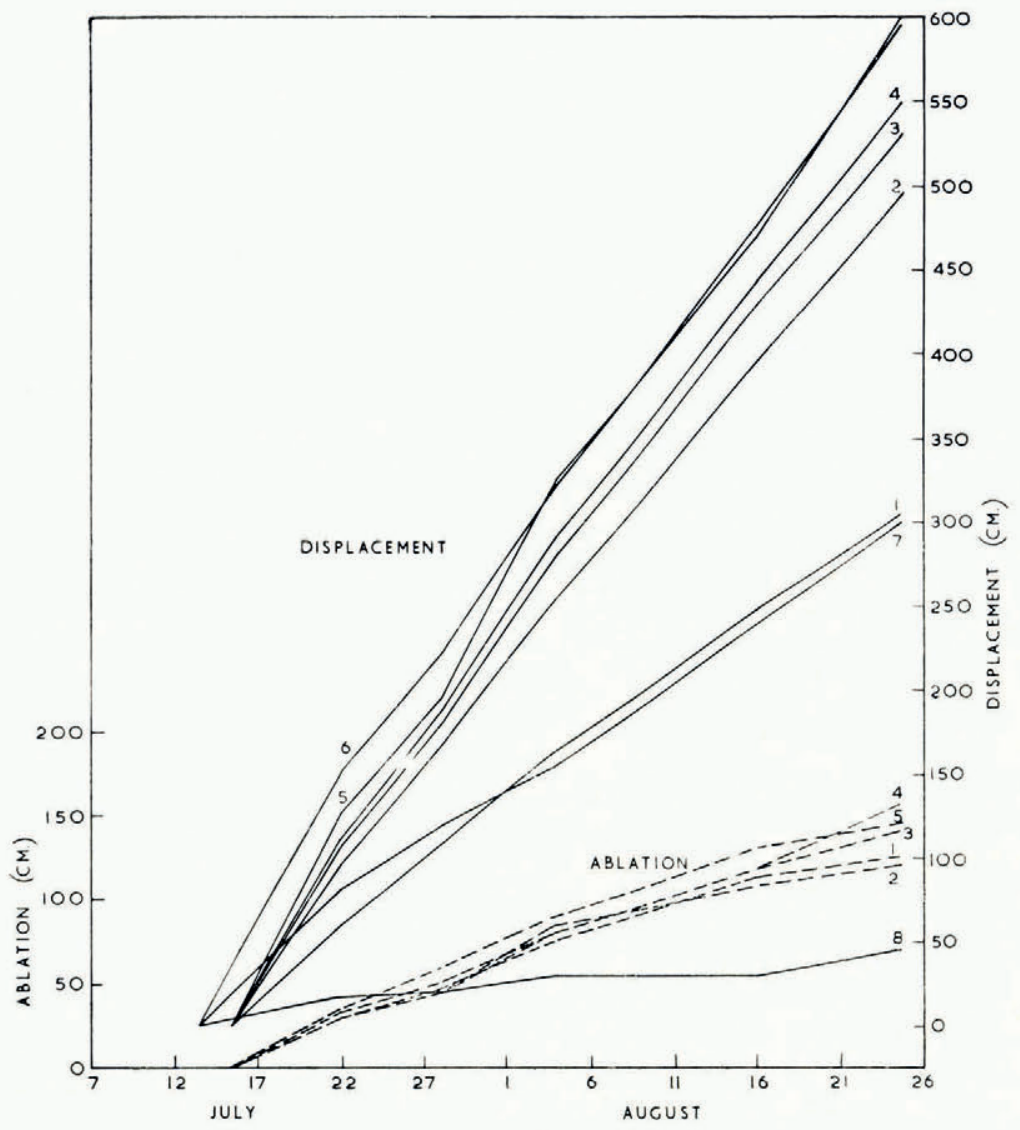

Fig. 4. Plots of the displacement and ablation against time in the top stake line

The table (Table I) shows the results of this procedure, which due to the obvious lack of correlation in the bottom stake line was only used for the upper two lines. The figures clearly demonstrate the correlation already described between ablation and flow.

There are however two singularities. The decrease in flow from week 3 to week 4 in the middle line was accompanied by an apparent increase in ablation. In fact the ablation error is large enough to conceal a decrease, as occurred on the upper line in this period. The other anomaly, the increase in flow velocity from weeks 4 to 5 on the upper line, will be discussed later.

Figure 7 shows a graph of the values from Table I plotted with the range of error. It will be noticed that a smooth curve (a straight line, in fact) can be drawn that is consistent with the standard deviation of all "points" except two. It will be seen that these "points" are those 


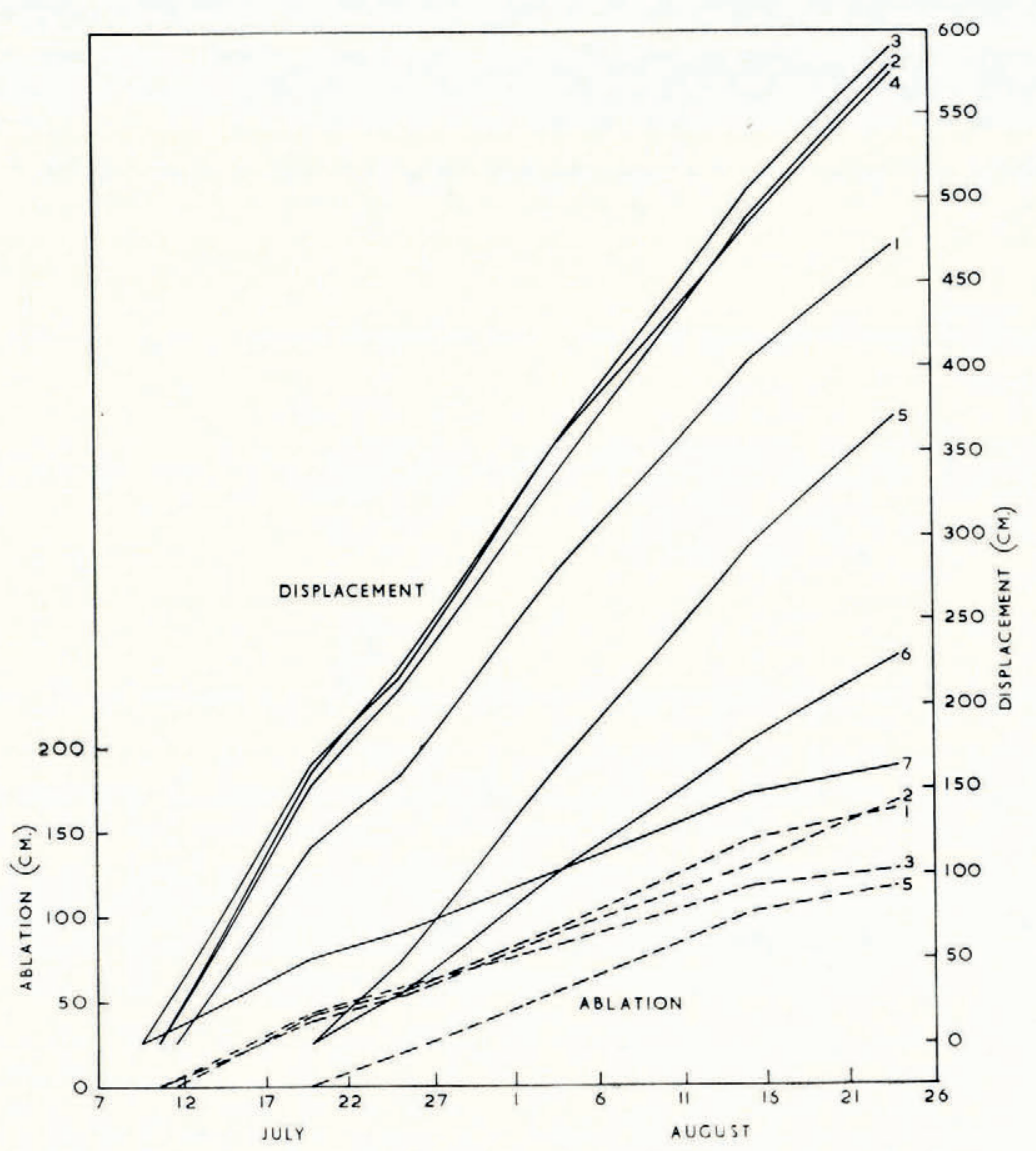

Fig. 5. Plots of the displacement and ablation against time in the middle stake line

corresponding to the last week. It is suggested that in this period the form of ablation changed such that the proportion of ice forming melt water increased. This is thought to have been due to a change of weather dominated by low-lying mist over this area of the glacier, preventing evaporation and sublimation. This weather is contrasted with clear skies and dry air during the previous weeks.

The lack of pattern shown by the lower line has three possible causes. One is that the small variations of ablation rate result in small fluctuations of velocity which are masked by local effects. A second possibility is that stakes 1,2 and 3 are to some extent independent of the others due to separate streams of flow (Battle, I95 I) caused by the presence of the ice fall, though there is no evidence for this from the mean flow pattern. Thirdly, as suggested by Weertman (1962), the subglacial water may have formed large streams in clearly defined channels instead of flowing in a sheet at the bed of the glacier.

In order to see if any daily variation of flow could be observed a stone marker was established in the bottom offset line. The magnitude of the errors of measurement, however, precluded drawing any definite conclusions on short-time fluctuations of flow of the glacier.

The results of the longitudinal stake line have not been included in the above presentation as although the pattern of velocity change is perhaps more marked, it is more difficult to interpret as only a very incomplete ablation record was made at each stake. No systematic 


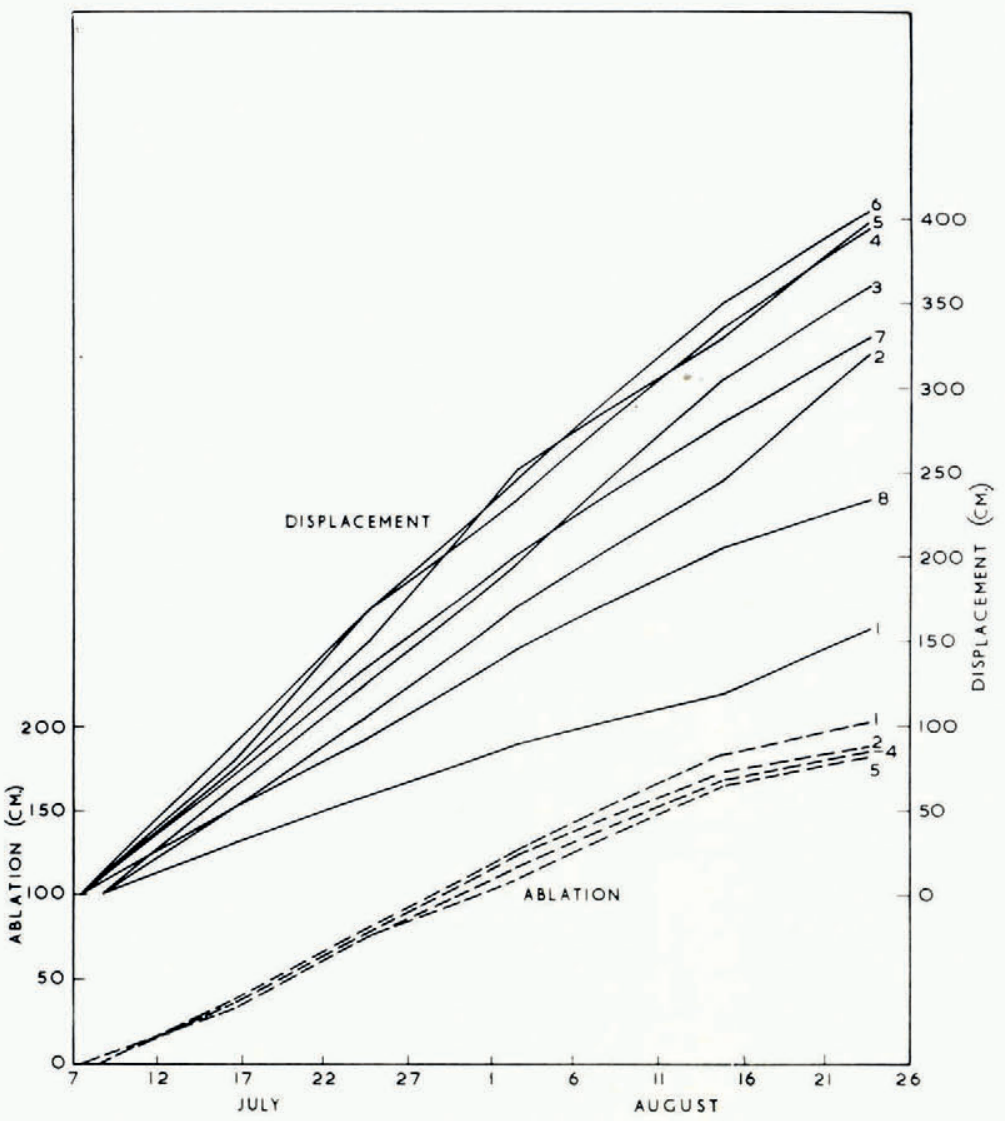

Fig. 6. Plots of the displacement and ablation against time in the bottom stake line

Table I. Correlation between Flow and Ablation

\begin{tabular}{|c|c|c|c|c|}
\hline & \multicolumn{2}{|c|}{ Top stake line } & \multicolumn{2}{|c|}{ Middle stake line } \\
\hline & $\begin{array}{c}\text { Normalized } \\
\text { flow }\end{array}$ & $\begin{array}{c}\text { Normalized } \\
\text { ablation }\end{array}$ & $\begin{array}{c}\text { Normalized } \\
\text { flow }\end{array}$ & $\begin{array}{c}\text { Normalized } \\
\text { ablation }\end{array}$ \\
\hline Week 1 & $1.32 \pm 0.03$ & $1 \cdot 5^{1} \pm 0.06$ & $\mathrm{I} \cdot 28 \pm 0.02$ & $1 \cdot 35 \pm 0 \cdot 15$ \\
\hline Week 2 & $0.87 \pm 0.04$ & $0.80 \pm 0.03$ & $0.81 \pm 0.01$ & $0.9 \pm 0.1$ \\
\hline Week 3 & $\mathrm{I} \cdot 09 \pm 0.03$ & $\mathrm{I} \cdot 3 \pm 0.15$ & $\mathrm{I} \cdot 05 \pm 0.02$ & $1 \cdot 00 \pm 0.05$ \\
\hline Week 4 & $0.86+0.03$ & $0.88+0.06$ & $0.97+0.02$ & $1.05+0.1$ \\
\hline Week 5 & $0.90=0.02$ & $0.6 \pm 0 . \mathrm{I}$ & $0.78 \pm 0.02$ & $0.5 \pm 0 \cdot I$ \\
\hline
\end{tabular}

variation suggestive of a wave moving down-glacier could be identified in the results from the longitudinal profile owing to the length of the interval between observations, eight days.

\section{Discussion}

Recently much attention has been given to the effect of subglacial water on bed-slip of a glacier both from theoretical (Lliboutry, I964; Weertman, I962) and experimental (Elliston in [Union Géodésique et Géophysique Internationale,] I963, p. 65-66) studies. Besides observations of increased velocity during the melting season (Battle, I95I ; Paterson, I96I), Elliston's results are the only so far obtained which support a relation between the melt-water run-off and surface flow. 


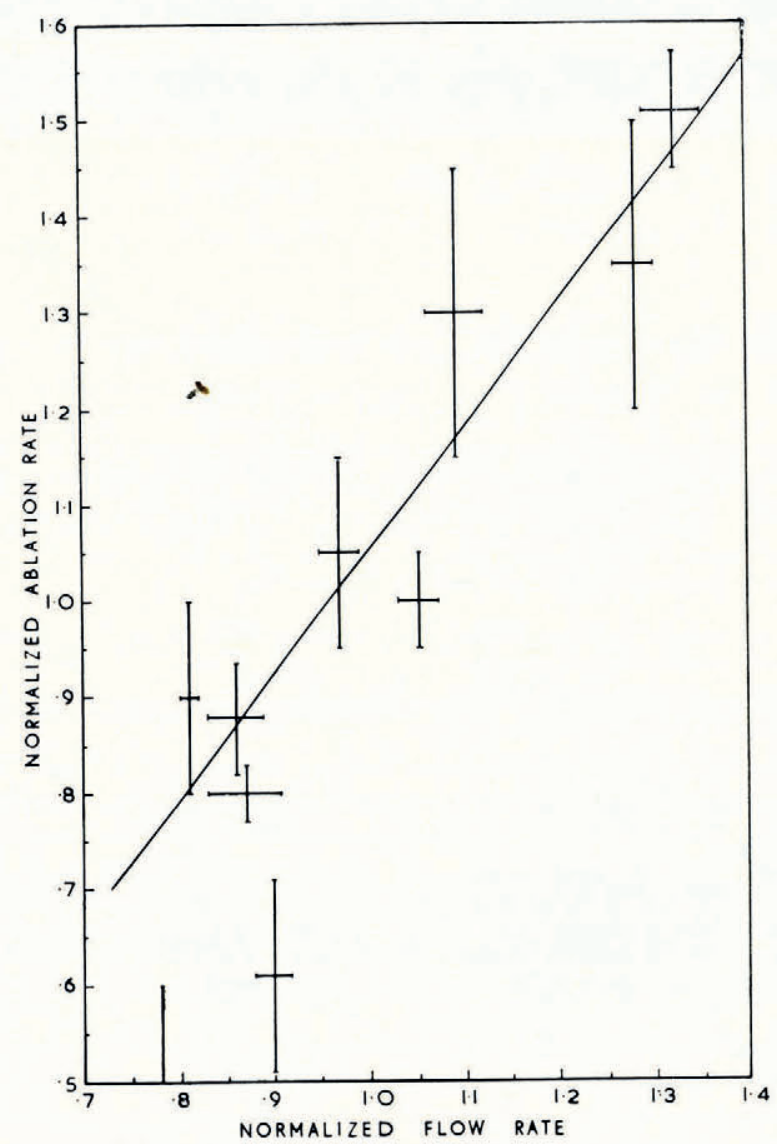

Fig. 7. Plot of the normalized flow velocity against normalized ablation rate

The results presented here are from a glacier believed to be sub-polar in character. As this demands a layer of the glacier to be below the freezing point of water it is not easy to see how the surface water can reach the glacier bed and modulate the surface speed. Before discussing this problem it is necessary to consider the evidence of the sub-polar nature of the Bersækerbræ. Unfortunately, the expedition was not equipped to measure ice temperatures, so the discussion is of a circumstantial nature. A freezing layer was observed in the lower part of the upper basin (at about I,250 m. a.s.l.) of the glacier at the end of August. Provided the altitude variation is not too great both Ahlmann (1948) and Schytt (1957) indicate that this probably implies negative ice temperatures in the ablation zone. During drilling early in July the drill frequently jammed and appeared to be frozen in its hole indicating negative ice temperatures down to a depth of $2.5 \mathrm{~m}$. Further evidence is provided by the mean annual air temperature at Mesters Vig (about ro $\mathrm{km}$. away at sea-level) of $-9 \cdot 7^{\circ} \mathrm{C}$. and by the observations of negative ice temperatures $\left(-\mathrm{IO}^{\circ} \mathrm{C}\right.$. at $3 \mathrm{~m}$.) by Sugden ( $\left.\mathrm{I} 96 \mathrm{I}\right)$ at similar altitudes in the neighbouring Sefstrøms Gletscher. Taking this all into account it appears that in the region of observation the glacier was sub-polar.

Despite the presence of the freezing zone the base of a polar glacier may be at pressure melting point, allowing water to be present in the liquid phase, due to geothermal heat and heat liberated by the sliding process. As the outflow from the Bersækerbræ was on bedrock we may assume the basal temperature was at pressure melting point in this region. In the 
area of observation only two surface streams were found, and these were not large enough to carry all the melt water from the region above. Much of the water must therefore have become either subglacial or englacial. As the freezing zone was apparently at a depth of 2 to $3 \mathrm{~m}$. the water must have penetrated this and, unless there were a second deeper freezing zone, become subglacial. There are two possible mechanisms by which the water may have passed through the freezing zone to reach the base of the glacier. Water flowing to the edge of the glacier may there become subglacial and then move in towards the centre. Alternatively water descending a crevasse may pass through the freezing zone and form a channel to the base. In fact small melt-water streams were seen descending into crevasses on the east side of the glacier. Some of these crevasses were filled with water, whereas others were empty, indicating an outlet to the latter which allowed water to escape through the freezing zone.

The results presented above indicate a relation between the surface flow and the subglacial melt-water run-off, if, as has just been shown, the latter is related to the ablation. This phenomenon may be due to "lubrication" of the bed by forcing a water layer between the rock and ice, thus decreasing the effective size of the obstructions to the flow. This process may be expressed by a low-power relation between the surface speed $(v)$ and the rate of subglacial run-off $(w)$ (i.e. $v \propto w^{n}$ where $o \leqslant n \leqslant 4$ ). Although a linear relation is indicated in Figure 7 there are insufficient values to justify any firm conclusions on this concept.

If the slip were uniform over the cross-section of the glacier there would be a significant variation in the proportional velocity changes across the glacier. No such variation was found except for stake 8 in the top line which generally showed any variations magnified, but was considered too inaccurate for detailed work.

Although the precise time response of the glacier flow to the ablation change could not be determined from these experiments because the intervals between successive observations were too large, it must have been less than 4 to 5 days, which compares with Elliston's measurements elsewhere.

In conclusion it is shown that even in polar regions, where the ice temperature may be below freezing to a considerable depth, the base of the glacier may still be at melting point. This allows the presence of the liquid phase of water, which will "lubricate" the bed of the glacier, and may cause variations in the surface speed by changing the basal slip.

\section{Acknowledgements}

The authors would like to thank the other members of the expedition for their efforts in making these sometimes dull observations. We would also like to thank the various grant aiding bodies, in particular the Mount Everest Foundation and Imperial College Exploration Board, for their assistance, and the Royal Geographical Society for the loan of surveying equipment during the expedition.

MS. received 4 August $19^{6} 4$

\section{REFERENGES}

Ahlmann, H. W. 1948. Glaciological research on the North Atlantic coasts. London, Royal Geographical Society. (R.G.S. Research Series, No. I.)

Battle, W. R. B. 1951. Glacier movement in north-east Greenland, 1949. Journal of Glaciology, Vol. I, No. Io, p. $559-63$.

Lliboutry, L. I964. Sub-glacial "supercavitation" as a cause of the rapid advances of glaciers. Nature, Vol. 202, No. 4927, p. 77 .

Paterson, W. S. B. ig61. Movement of the Sefstrøms Gletscher, north-east Greenland. Journal of Glaciology, Vol. 3, No. 29 , p. $844-49$.

Schytt, V. 1957. [Letter.] (In The classification of glaciers. Journal of Glaciology, Vol. 3, No. 2 1, p. 3-4.)

Sugden, J. C. G. Unpublished. Some ice temperatures in the Sefstroms glacier. [Report of the ig6o Greenland expedition, dated $196 \mathrm{I}$; in the Royal Geographical Society Library.]

[Union Géodésique et Géophysique Internationale.] 1963. Colloque d'Obergurgl (suite). Bulletın de l'Association Internationale d'Hydrologie Scientifique, 8e An., No. 2, p. 50-142.

Weertman, J., I962. Catastrophic glacier advances. Union Géodésique et Géophysique Internationale. Association Internationale d'Hydrologie Scientifique. Commission des Neiges el Glaces. Colloque d'Obergurgl, IO-9-18-9 1962, p. 31-39. 